\title{
P-013 唾液腺腫瘍73例の検討
}

\author{
○田浦政彦、小池健輔 \\ 佐世保共済病院
}

2011年 4 月から2016年11月までの間に当科で治療を行った崜液腺腫瘍73例に関して検討を行った。男性33例、女性40例、 年齢は18～88歳まで、平均年齢は57歳であった。耳下腺腫瘍58例、顎下腺腫瘍 13 例、舌下腺腫瘍 2 例と耳下腺腫瘍が最も多 かった。73例の内訳は悪性腫瘍 11 例、良性腫瘍50例、炎症性疾患12例と良性腫瘍が多かった。耳下腺腫瘍は悪性 4 例、良性 46 例と良性腫瘍が多かったが、顎下腺腫瘍は悪性 5 例、良性 4 例、舌下腺腫瘍は悪性 2 例であり、顎下腺と舌下腺では悪性 腫瘍が多かった。悪性腫瘍の組織型は腺様囊胞癌 5 例、唾液腺導管癌 4 例、扁平上皮癌 1 例、腺房細胞癌 1 例であった。良 性腫瘍は多形腺腫36例、ワルチン腫瘍14例であり、多形腺腫は女性に多く、ワルチン腫瘍はすべて男性であった。検查別正 診率は、超音波検査46\%（30/64例)、MRI 検査73\%（44/60例）、細胞診検査72\%（44/61例）であり、超音波検査で唾液腺 腫瘍を診断するのは困難であると考えられた。悪性腫瘍は細胞診検査での正診率（71\%）が高く、良性腫瘍は MRI 検査で の正診率 $(88 \%)$ が高かった。

\section{P-014 当科における耳下腺多形腺腫再発症例の検討}

○登米 慧、椎名和弘、川菩洋平、鈴木真輔、本田耕平 秋田大学 医学部 耳鼻咽喉科

耳下腺に発生する多形腺腫は、耳下腺腫瘍の過半数を占める良性腫瘍である。治療は外科的切除が第一選択であるが、不 十分な切除で再発する可能性が高くなる。再発例では腫瘍が多発する場合が多く、再手術時の顔面神経損傷の恐れが大きく なるため治療に難渋することが多い。当科で2003年 1 月から2015年12月までに経験した耳下腺多形腺腫再発症例10例に関し て検討した。内訳は男性 1 例、女性10例。年齢は平均56歳。初回手術から再発までの期間は平均 14 年であった。再発後手術 時に顔面神経の切断を要した症例が 4 例あったが、うち 1 例では完全回復し、3 例は軽度（柳原法20点以上）の術後顔面神 経麻瘒のみであった。術後再再発例が 1 例みられた。これらの症例の一部を提示し、若干の文献的考察を加えて報告する。

\section{P-015＼cjkstart当科における耳下腺手術症例の臨床統計}

○玉江昭裕、野田哲平、友延恵理、西山和郎 国家公務員共済組合連合会浜の町病院

2010年 4 月より 2016年 3 月までの 6 年間における当科の耳下腺手術症例178例について検討した。病理診断は多形腺腫が 60 例、ワルチン腫瘍が54例、リンパ上皮囊胞が 9 例、基底細胞腫が 8 例、悪性リンパ腫が 6 例、癌腫が 21 例、その他が 18 例 であった。当科においては術前検査として、エコー、細胞診、ダイナミックスタデイを含む造影 MRを行っている。最終 病診断と、術前診断の関係を中心に検討する。

\section{P-016 当院で経験した巨大多形腺腫の一例}

○津曲省吾、川畑隆之、井手慎介、東野哲也 宮崎大学医学部付属病院 耳鼻咽喉科

【はじめに】耳下腺多形腺腫は近年画像評価の発達のため、数 $\mathrm{cm}$ 程度の比較的小型の時に診断されることが多い。しか し長年放置され巨大化する例も散見され、時に悪性化している症例も検討する。今回われわれは、30年以上前に手術後、再 形成された腫瘤が徐々に巨大化し治療した耳下腺多形腺腫の一例を経験したので報告する。【症例】60歳男性【現病歴】45 年前左頸部腫瘤を自覚し、近医外科にて切除術を行った。33年前頃から再度腫瘤を自覚したが、特に症状もないことから放 置していた。3 年前から徐々に増大してきたため、当科受診となった。来院時左下顎部に直径 $30 \mathrm{~cm}$ 程度の弾性硬な腫瘤を 認めた。疼痛や顔面神経麻瘏、咽頭狭窄などは認めなかった。CT にて左耳下腺から下顎部・前頸部に広がる最大径 $30 \times 20$ $\times 20 \mathrm{~cm}$ の多房性腫瘤性病変を認め、細胞診で多形腺腫と診断された。【経過】左耳下腺腫瘍摘出術を施行した。腫瘍部分 の皮膚は併せて合併切除し、DP 皮弁による再建を行った。現在までのところ、術後経過良好で術後顔面神経麻㾝などの合 併症は認めていない。 


\title{
P-017 耳下腺結核の一例
}

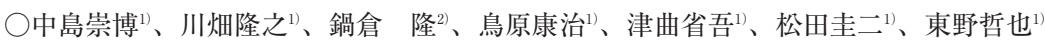

宮崎大学 医学部 耳鼻咽喉・頭頸部外科 ${ }^{1}$ 、県立宮崎病院 耳鼻咽喉科 ${ }^{2}$

耳鼻咽喉科領域の肺外結核を診断する機会は少ないものの診断確定すれば直ちに届出を必要とする重要な疾患の一つであ る。今回比較的まれな耳下腺結核の一例を経験した。統合失調症がある40歳男性。某精神病院に措置入院中のX年 9 月 2 日 より左耳周囲の腫脹疼痛出現。頸部 CT にて頸部膿瘍と診断され26日切開排膿受けた。10月17日耳前部腫脹出現。CT 再検 查にて膿瘍再発が疑われ11月 7 日当科紹介。呼吸器症状や持続する発熱なし。左㚘部腫脹と開口障害あり、造影 CTでは左 耳下腺炎と膿瘍を認めた。クォンティフェロン陽性で胸部 CT にて肺結核所見なし。穿刺吸引細胞診では腫瘍陰性、チール 染色陰性であったが、11月30日培養検查で抗酸菌陽性判明、同日の PCRにて結核菌の確定診断となったため同日結核専門 病院へ紹介。頭頸部の肺外結核は頸部リンパ節が最も多く唾液腺は比較的まれである。本例は発症時に顎下リンパ節腫脹を 合併しており、リンパ行性感染と思われた。また、年余にわたる精神疾患歴がリスク因子として考えられた。

\section{P-018＼cjkstart頸部結核性リンパ節炎 6 例の検討}

○藤原良平、木村隆幸、西原美沙子、白石 功、小林孝光、森川大樹、速水康介、北野睦三、土井勝美 近畿大学 医学部 耳鼻咽喉科学教室

頸部リンパ節腫脹を来す疾患は多岐にわたり、その中で結核性リンパ節炎は現在も日常診療で遭遇する比較的まれな疾患 である。今回われわれは2013年 1 月から 2015 年 12 月の 3 年間で 6 例の頸部結核性リンパ節炎を経験したので報告する。平均 年齢は67歳 (44 85歳)、性別は男性 3 例、女性 3 例であり、1 例に肺結核の既往を認めた。穿刺吸引細胞診を施行した 5 例中 1 例は結核の疑いであったが、抗酸菌の塗抹・培養・PCR はいずれも陰性であった。画像検査では、造影 CT 検査を施 行した 3 例中全例で中心壞死像を認めたが、石灰化像は 6 例全例に認めなかった。FDG-PET は全例に施行し、結核性リン パ節炎が疑われる部位は SUV4. 3-10.2 の比較的高い集積を認めた。リンパ節の腫脹部位は、頸部限局が 2 例、頸部と縦隔 が 3 例、全身のリンパ節が 1 例であった。結核性リンパ節炎は個々の検査の診断率が低く診断に難渋することがあるため、 まずは疾患を念頭に入れ精査をすすめる必要がある。本症例の経過に若干の文献的考察を加えて報告する。

\section{P-019Ｔh17 サイトカインのヒト鼻粘膜上皮細胞におけるフィラグリン発現の制御}

\author{
○中村真浩 ${ }^{122}$ 、神谷和作 ${ }^{11}$ 、池田勝久 ${ }^{11}$ \\ 順天堂大学 医学部耳鼻咽喉科学講座 ${ }^{1}$ 、順天堂大学 大学院医学研究科アトピー疾患研究センター2)
}

フィラグリンは、表皮の顆精細胞で産生される塩基性タンパク質の一種で、ケラチンフィラメントの凝集効率や角層中の 保湿と $\mathrm{pH}$ の保持を担い、皮膚のバリア機能に重要な役割を果たしている。現在、バリア機能低下と、アトピー性疾患の発 症の関連は注目されている。われわれは鼻粘膜上皮に拄けるフィラグリンの発現と局在について解析を行ってきた。正常七 卜鼻粘膜上皮細胞の培養を行い、リアルタイム PCR 法による mRNA の測定を行いフィラグリンの発現を検討し、鼻粘膜上 皮細胞においてフィラグリンの発現を確認した。これまで鼻粘膜上皮のフィラグリンの制御にかかわる報告に、TLRリガ ンドや TNF $\alpha$ 刺激によるフィラグリンの down regulation を示すものがあるのみであった。われわれは今回 Th17 サイトカ イン刺激によって鼻粘膜のフィラグリンの発現の変化を評価したので、文献的考察を加えて報告する。

\section{P-020Ｓykによりチロシンリン酸化された 3BP2 の貪食細胞における機能}

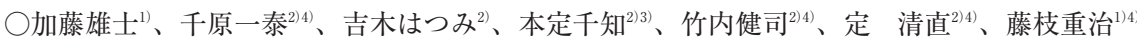

福井大学 医学部 耳鼻咽喉科・頭頸部外科 ${ }^{11}$ 、福井大学 医学部 ゲノム科学・微生物学分野 ${ }^{2}$ 、

福井大学 医学部 第 3 内科 ${ }^{3}$ 、福井大学 ライフサイエンスイノベーションセンター4)

【目的】3BP2 はヒト遺伝病チェルビズムの原因遺伝子として同定されている。今回、単球/マクロファージ系に分化する 細胞株 U937 を用いて、3BP2 がかかわるシグナル伝達と細胞応答について解析を行った。

【結果】U937 細胞に対して CRISPR/Cas9 システムによるゲノム編集を行い、さまざまなシグナル伝達分子をノックアウ ト（KO）した細胞株を樹立した。樹立した細胞株を IFNー Syk に依存した 3BP2 のチロシンリン酸化が確認できた。オプソニン化 zymosan を用いて領食能を解析すると、Sykによる リン酸化を受けない変異体では野生型に比べて食作用が低下していた。さらに、高親和性 IgG 受容体刺激による IL-8の遺 伝子発現においても低下を認めた。

【結論】3BP2 は、Syk によるチロシンリン酸化を受け、領食や IgG 受容体刺激によるサイトカインの産生を調節すると考 えられた。今後は慢性副鼻腔炎患者の病態との関連について明らかにしていく所存である。 